\title{
The changing face of corporate venturing in biotechnology
}

\author{
Georg von Krogh, Boris Battistini, Fotini Pachidou \& Pius Baschera
}

Corporate venture funds are playing an increasingly important role in supporting life science commercialization.

\begin{abstract}
orporate venturing-the practice of estab$\smile$ lishing a unit of a corporation with the mandate to make strategic investments in entrepreneurial ventures-has emerged as one of the most prominent strategies for opening up innovation to external ideas and knowledge in the life sciences. Venture arms of pharmaceutical and large biotech companies leverage capital surplus generated through traditional revenue streams to create options for future product pipelines, enable access to innovative compounds and share the costs of risky early stage development with external partners. Motivated by the increasing supply of-and demand for-corporate venture capital (VC) in biotech, we have conducted a global study (Corporate Venturing Research Initiative) of leading corporate venture units $(\mathrm{n}=48)$ in collaboration with management consultancy Bain \& Company in Boston, adopting a systematic, multiphase research design that includes primary data collection using survey methodology, expert interviews and an industry subsample of ten high-profile venture units at corporations, such as Roche in Basel, Switzerland, Merck Serono in Geneva, Novartis in Basel and GlaxoSmithKline (GSK) in London. Based on this study, we identify six new principles of corporate venturing that reflect past learning in this field by pharmaceutical firms and an improved understanding of biotech ventures. We also propose criteria
\end{abstract}

Georg von Krogh is chair of strategic management and innovation, Boris Battistini is a research associate and project leader of the Corporate Venturing Research Initiative (with Bain \& Company), Fotini Pachidou is a research associate, and Pius Baschera is chair of entrepreneurship in the Department of Management, Technology and Economics, ETH Zurich, Zurich, Switzerland. e-mail:gvkrogh@ethz.ch that biotech entrepreneurs can use to judge the appropriateness of partnering with a corporate venture fund.

\section{Toward new principles}

For the biotech industry, corporate venture investing is entering a new era of opportunity, with activities accounting for an aggregate $\$ 3$ billion of investment rounds and the recent establishment of venture funds at Merck, based in Whitehouse Station, New Jersey; Boehringer Ingelheim, based in Ingelheim, Germany; and Baxter based in Deerfield, Illinois. From January 1, 2011 to June 30, 2012, data from the National Venture Capital Association in Washington, DC, and consultancy PricewaterhouseCoopers in New York $^{1}$ suggest that corporate venture capital funds were involved in $19.4 \%$ of all deals in the biotech sector, with $\$ 495$ million invested out of the total $\$ 6.4$ billion. The increased deal making is also signaled by the presence of 4 corporate venture arms in the top 20 of the most active venture capital investors as ranked by number of 2011 financings ${ }^{2}$.

The rise of corporate venturing coincides with a shortage of fresh capital for new biotech ventures in the US, Europe, China and India ${ }^{3,4}$. Although biotech has been one of the most active areas for VC investments-measured by deals and equity invested ${ }^{1}$ - the harsh reality facing biotech entrepreneurs today is a shrinking traditional VC market and growing competition to secure funding.

In spite of consistently above average returns on biotech ventures ${ }^{5}$, several traditional VC funds are shifting their investments away from the high-risk, early stage financing of biotech startups and into later-stage opportunities and existing portfolios. The fewer VC funds that do specialize in early stage biotech investments have consequently become increasingly more selective and unable to meet the greater demand for patient capital ${ }^{2}$. These developments make pharmaceutical-induced corporate venture funds ever more important. Traditionally less sensitive to fluctuations in financial markets than firms in many other industries (for example, construction), healthcare and biotech firms have emerged as cash-rich investors with an appetite for new venture deals. However, biotech entrepreneurs have traditionally been skeptical about striking deals with corporate venture units, citing the slow pace of decision making of pharmaceutical companies, internal bureaucracy, ambiguous investment objectives of such units, turnabouts in strategic direction and changes in top management. Corporate venture units have also often been perceived as having a corporate rather than a venture mindset ${ }^{6}$, reflecting both their typical corporate incentive schemes and their peripheral participation in deal structuring and the VC communities.

On the basis of the results of our survey, more than two-thirds of the established corporate venture units we examined reported substantial changes over the past decade in their structure, strategic scope and human capital. Many of these changes are reflected in the transparency of funding, organization structure and the VC-like practices of newly established venturing initiatives, such as the $\$ 134$ million 'evergreen' venture fund that Boehringer Ingelheim launched in 2010 or the $\$ 50$ million Strategic Investment Group, the venture capital arm of Basingstoke, UK-based Shire.

Pharmaceutical firms have developed larger and more sophisticated venture units, which today take a more active role in syndicates and deliver greater value to co-investors and entrepreneurs (Table 1). The contribution of corporate VC investment to a syndicate is twofold: financial resources and highly specialized market knowledge of the pharmaceutical industry, which can be of decisive importance in an exit environment driven by strategic 
deals and acquisitions. Indeed, according to a recent report by San Francisco-based Burrill \& Company ${ }^{7}$, which examined all 5,100 rounds of therapeutic venture investments made between 2000 and 2011, companies that receive corporate venture funding are more likely to achieve a successful exit-via initial public offering (IPO) and merger and acquisition (M\&A) - and enter into licensing or collaboration agreements.

Recently, we have also observed innovative fund concepts launched to complement well-established venturing efforts. Novartis BioVentures, based in Cambridge, Massachusetts, created an alternative venturing vehicle, the US\$200 million Option Fund, with the scope to provide seed capital to highly innovative ventures during their earliest stages. The Option Fund, a limited-scope seed fund that also provides nondilutive investments in a secondary development project in return for a limited option right, represents a prime example of a new business model in biotech corporate venturing ${ }^{8}$. Lilly Ventures in Indianapolis launched the innovative Mirror Portfolio, which integrates three independent venture funds for external molecule developments and, thus, allows cost- and profit-sharing deals with a variety of external partners. Additionally, corporate venturing is going international. Earlier this year, Takeda, based in Osaka, Japan, reorganized its corporate research-funding unit Takeda Research Investment into Takeda Ventures, based in Palo Alto, California, with the purpose of expanding its external venture activities outside of Japan and providing competitive intelligence on emerging technologies.

\section{Six principles of corporate venturing}

Pharmaceutical firms currently face extraordinary opportunities to leverage corporate venturing in remodeling their innovation and investment practices ${ }^{9}$. For startups funded in this manner to succeed, however, corporate venturing itself must abandon the traditional corporate mindset and become a partner that is on equal footing with the founders and other early stage investors. Our research has revealed six principles consistently adopted by the firms in our sample, which are redefining today's corporate venturing.
Develop a strong mandate. In the past, pharmaceutical firms tended to change their venture strategy every few years. Corporate venture units were often short lived, and their investment programs lacked credibility. Prior research has shown that the average lifespan of corporate venture programs is currently approximately 4 years, with $>40 \%$ active for longer, whereas the average duration was 2.5 years in the previous decade ${ }^{10}$. Dwindling mandates by firms generated antagonistic perceptions among entrepreneurs and investors, which resulted in negative repercussions on performance, such as inadequate access to high-quality deal flow. Today, most pharmaceutical firms take a longerterm view of equity investments by providing a strong mandate to corporate venture units from the executive team and board of directors. Several corporate venture funds used to report to the firm's head of R\&D, but today many of the funds report directly to the CEO. Consistently in our sample, the majority of the corporate venture units reported directly to the executive team (50\%), including the CEO, or to the chief strategy officer (20\%). A strong mandate and

Table 1 Syndicated venture deals with at least one corporate venture arm among the investors (2009-2012*).

\begin{tabular}{|c|c|c|c|c|}
\hline \multirow[b]{2}{*}{ Company (location) } & \multirow[b]{2}{*}{ Date } & \multirow{2}{*}{$\begin{array}{l}\text { Round/size } \\
\text { (millions) }\end{array}$} & \multicolumn{2}{|c|}{ Investment syndicate } \\
\hline & & & Corporate venture investors & Traditional venture investors \\
\hline $\begin{array}{l}\text { Aileron Therapeutics } \\
\text { (Cambridge, Mass.) }\end{array}$ & 06/08/09 & $\mathrm{D} / \$ 40$ & $\begin{array}{l}\text { Lilly Ventures, SR One, Roche Venture Fund and } \\
\text { Novartis Venture Funds }\end{array}$ & Excel Medical Ventures and Apple Tree Partners \\
\hline Epizyme (Cambridge, Mass.) & $12 / 08 / 09$ & $\mathrm{~B} / \$ 40$ & $\begin{array}{l}\text { Amgen Ventures and Astellas Venture } \\
\text { Management }\end{array}$ & $\begin{array}{l}\text { New Enterprise Associates, Bay City Capital, MPM } \\
\text { Capital and Kleiner Perkins Caufield \& Byers }\end{array}$ \\
\hline $\begin{array}{l}\text { Neuro Therapeutics Pharma } \\
\text { (Chicago) }\end{array}$ & $05 / 20 / 10$ & $\mathrm{~B} / \$ 43$ & $\begin{array}{l}\text { SR One, Pfizer Venture Investments and Novo } \\
\text { Ventures }\end{array}$ & $\begin{array}{l}\text { Fidelity Biosciences, MPM Capital and Thomas } \\
\text { McNerney \& Partners }\end{array}$ \\
\hline Syntaxin (Abingdon, UK) & $11 / 11 / 10$ & $\mathrm{C} / \$ 29$ & $\begin{array}{l}\text { Ipsen, SR One, J\&J Development and } \\
\text { Lundbeckfond Ventures }\end{array}$ & $\begin{array}{l}\text { Abingworth, Life Sciences Partners, Seventure Partners } \\
\text { and Quest for Growth }\end{array}$ \\
\hline $\begin{array}{l}\text { Genocea Biosciences } \\
\text { (Cambridge, Mass.) }\end{array}$ & $02 / 01 / 11$ & $\mathrm{~B} / \$ 35$ & SR One and J\&J Development & $\begin{array}{l}\text { MP Healthcare Venture Management, Skyline Ventures, } \\
\text { Auriga Partners, Cycad Group, Alexandria Real Estate } \\
\text { Equities, Lux Capital Management, Polaris Venture } \\
\text { Partners and Morningside Ventures }\end{array}$ \\
\hline Symphogen (Copenhagen) & $06 / 01 / 11$ & N.D./\$131 & Novo Ventures & PKA and Essex Woodlands Health Ventures \\
\hline $\begin{array}{l}\text { Nimbus Discovery } \\
\text { (Cambridge, Mass.) }\end{array}$ & $06 / 28 / 11$ & $A / \$ 24$ & SR One and Lilly Ventures & Atlas Venture and Bill \& Melinda Gates Foundation \\
\hline $\begin{array}{l}\text { Atlas Genetics } \\
\text { (South Bath, UK) }\end{array}$ & $07 / 01 / 11$ & $\mathrm{~B} / \$ 27.6$ & Novartis Venture Funds and J\&J Development & $\begin{array}{l}\text { Consort Medical, BB Biotech Ventures, Life Sciences } \\
\text { Partners, YFM Equity Partners, Braveheart Investment } \\
\text { Group, Crescent Seedcorn Fund and Wyvern Asset } \\
\text { Management }\end{array}$ \\
\hline $\begin{array}{l}\text { DVS Sciences } \\
\text { (Sunnyvale, Mass.) }\end{array}$ & $07 / 01 / 11$ & $A / \$ 14.6$ & $\begin{array}{l}\text { Pfizer Venture Investments and Roche Venture } \\
\text { Fund }\end{array}$ & $\begin{array}{l}\text { 5AM Ventures, Mohr Davidow and Ontario Institute for } \\
\text { Cancer Research }\end{array}$ \\
\hline Creabilis (Sandwich, UK) & $10 / 01 / 11$ & $\mathrm{~B} / \$ 20$ & Abbott Biotech Ventures & NeoMed and Sofinnova Partners \\
\hline Imagen Biotech (New York) & $10 / 01 / 11$ & $\mathrm{~A} / \$ 40$ & Novo Ventures & SV Life Sciences and Fidelity Biosciences \\
\hline Celladon (Indianapolis) & 05/01/12 & $\mathrm{D} / \$ 53$ & $\begin{array}{l}\text { J\&J Development, Lundbeckfond Ventures, } \\
\text { Novartis Venture Funds and Pfizer Venture } \\
\text { Investments }\end{array}$ & $\begin{array}{l}\text { Enterprise Partners Venture Capital, GBS Venture } \\
\text { Partners, H\&Q Healthcare Investors and Hambrech \& } \\
\text { Quist Capital Management }\end{array}$ \\
\hline $\begin{array}{l}\text { Sutro Biopharma } \\
\text { (S. San Francisco) }\end{array}$ & 05/08/12 & $\mathrm{c} / \$ 36.5$ & Lilly Ventures and Amgen Ventures & Skyline Ventures, SV Lifesciences and Alta Partners \\
\hline $\begin{array}{l}\text { PhaseBio Pharmaceuticals } \\
\text { (Malvern, } \mathrm{Pa} \text {.) }\end{array}$ & $07 / 31 / 12$ & $\mathrm{~B} / \$ 23.2$ & $\begin{array}{l}\text { Astellas Venture Management and J\&J } \\
\text { Development }\end{array}$ & New Enterprise Associates \\
\hline Auxogyn (Menlo Park, Calif.) & 07/01/12 & $\mathrm{B} / \$ 18$ & SR One and Merck Serono Ventures & Kleiner Perkins Caufield \& Byers and TPG Biotech \\
\hline
\end{tabular}

Source: Global Corporate Venturing (London) and Corporate Venturing Research Initiative (Zurich).

*Up to July 1, 2012. N.D., not disclosed. 


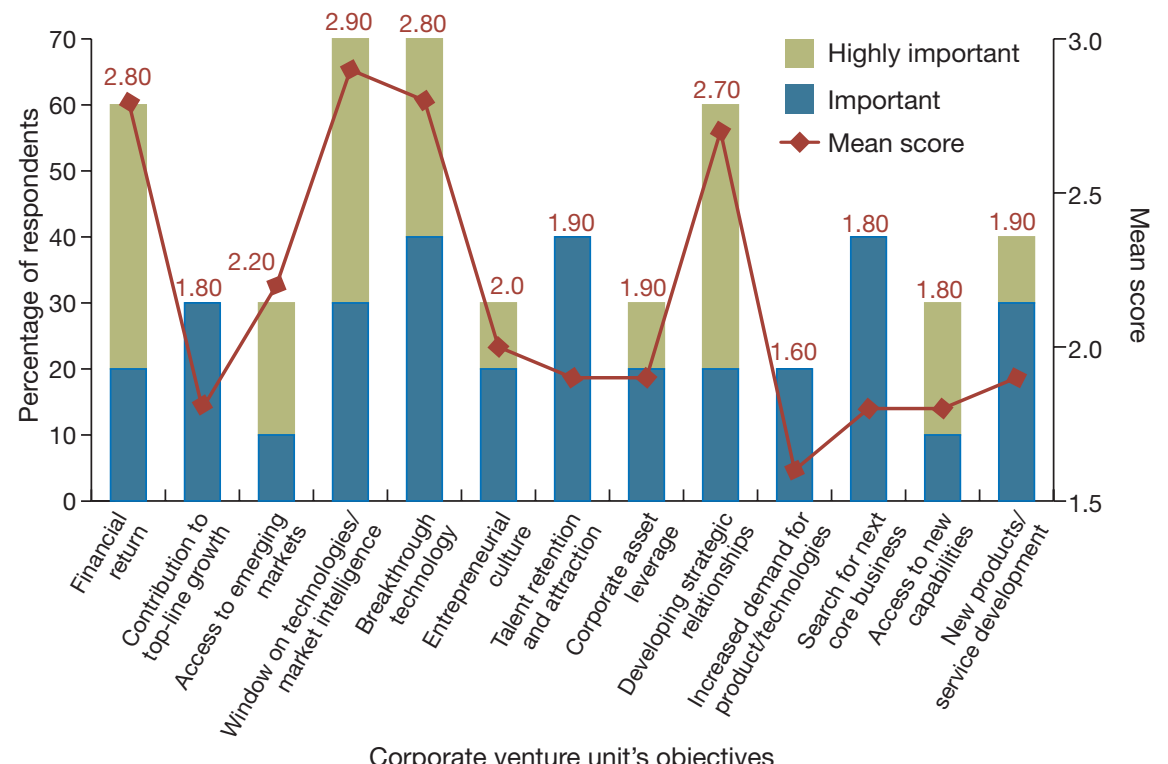

Figure 1 Percentage of importance and frequency (mean score: $\min =1.0, \max =3.0$ ) of investment objectives at corporate venture capital funds.

the involvement of senior management ensure faster decisions, consistency of approach and follow through on commitments on behalf of the corporate parent toward co-investors and biotech ventures.

Emphasize focus and discipline in investment strategy. A second principle is that corporate VC funds should take a variety of approaches for venture investing, ranging from a largely return-based approach to a more strategic

a

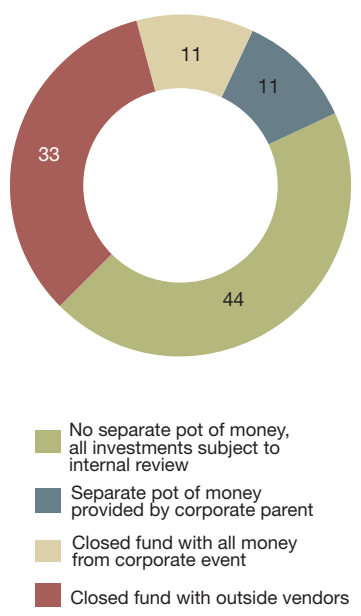

orientation. The approach chosen can be expected to importantly influence the investment objectives in place. We have observed, in our sample, that an increasing number of corporate venture units report having multiple investment objectives. Although financial returns are consistently considered essential, three other objectives emerged as important: providing a window on technology/market trends, developing strategic relationships and accessing breakthrough technology (Fig. 1).
For corporate venture units whose mandate includes being strategically relevant and creating value for the parent firm, the investment objectives need to follow a disciplined execution approach to ensure effective compliance with investment criteria and need to be consistent with the broader innovation agenda ${ }^{11}$ (such as staying aware of new therapeutic areas). For example, Merck Serono Ventures in Geneva, the $\$ 60$ million fund of Darmstadt, Germanybased Merck Serono, has a clear focus on investing in therapeutic areas with a considerable strategic overlap with the corporate parent. Additionally, to ensure a fit between the firm and its investments, the newly established Boehringer Ingelheim Venture Fund decided to define a clear scope limiting its investments to six target areas, including new-generation vaccines and new biological entities. In such cases, the role of the fund is to complement, rather than substitute, the existing approaches of the firm (for example, R\&D, and licensing and research collaborations). Overall, a focused investment strategy reduces the goal ambiguity that hampered corporate venturing in the past.

Ensure autonomy. Successful corporate venturing in our sample relied on autonomous governance structures. Indeed, our study indicated that pharmaceutical firms are increasingly structuring their venturing effort as a separate fund (Fig. 2a).

Three-quarters of the corporate venture units enjoyed financial autonomy with either a separate budget-that is, not subject b

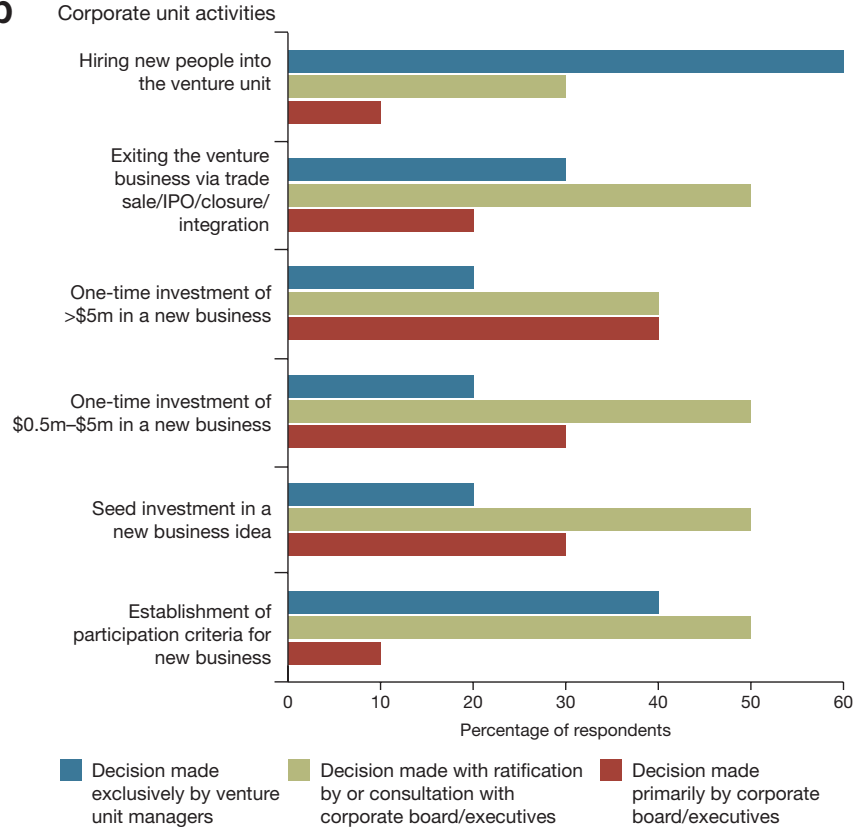

Figure 2 Structure and major activities of corporate venture capital funds in the survey. (a) Types of unit financing expressed as percentage of respondents. (b) Frequency (\%) of decision makers regarding the corporate venture unit's activities. 
a

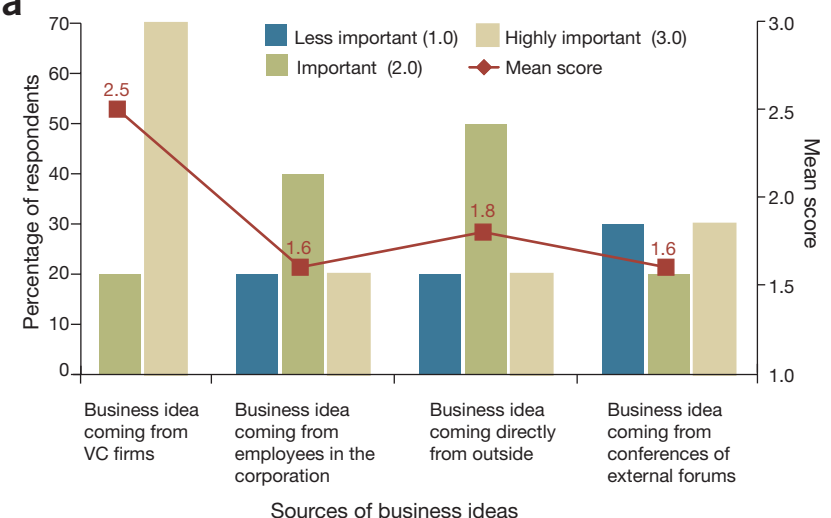

b

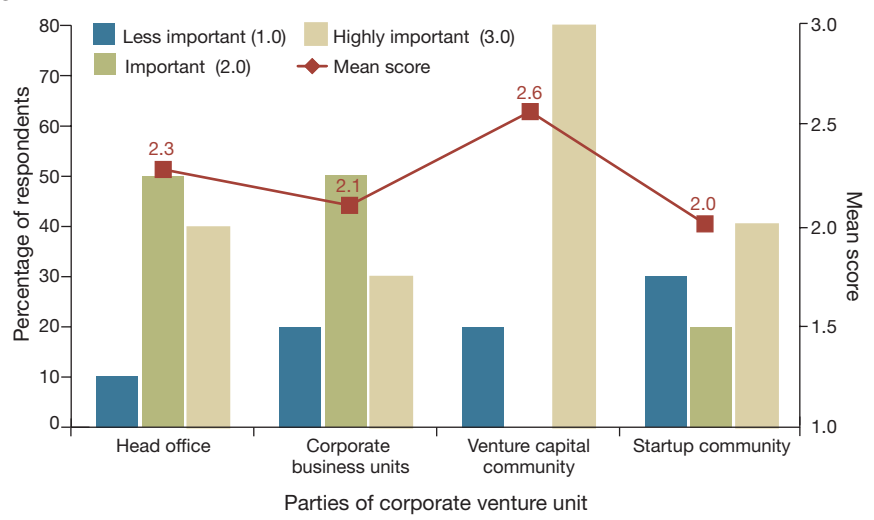

Figure 3 The importance of internal and external networks for corporate venture units. (a) Importance of the relationship with different parties for the corporate venture unit. (b) Importance of sources for obtaining new business ideas and/or business proposals.

to internal review (44\%)-or a closed-fund structure (22\%). Moreover, the management of the venturing activities and strategic investments showed considerable decision-making autonomy (Fig. 2b). Although most of the newly established corporate VC units had an autonomous governance structure from the beginning, other firms have reorganized their corporate venturing efforts along the same lines. A prominent example is the 2009 spinout of Lilly Ventures, Eli Lilly's venture capital arm, which was founded in 2001. Overall, most venture units today independently decide on strategic investments and portfolio development, limiting internal conflicts of interest and the short-term performance requirements that had previously troubled corporate venturing.

Secure external legitimacy and participate actively in startup. The importance of securing external legitimacy and corporate VC funds' active involvement in investments is a fourth key principle that emerged from our analysis. For corporate venture units, it is crucial to be embedded in the VC investor community. Building and sustaining relationships with traditional VCs enables such units to identify opportunities. The respondents in our sample considered the community the single most valuable source of high-volume, high-quality deal flow (Fig. 3), much more so, for example, than the firm itself.

However, achieving external legitimacy in the VC community has never been an easy task for corporate venture units. Venture capitalists historically regarded such units as unreliable partners unable to contribute to the effective functioning of syndication networks. The lack of long-term commitment, multiple strategic objectives and slow decision making, all exacerbated by complex corporate processes and substantial differences in the focus on financial returns, were frequently reported reasons why
VCs were cautious about syndicating deals with corporate venture units. However, during the past few years, pharmaceutical firms appear to have learned their lessons. Our study showed that corporate venture units have been moving away from a passive investor role with limited involvement to become a sophisticated investment partner capable of participating in larger and more prominent syndication. In fact, $90 \%$ of the surveyed firms indicated more than two partners involved for a typical external investment of their venture unit. Often, units even lead or co-lead financing rounds. Today, corporate ventures are involved in the development of their portfolio startups, frequently (up to 60\%) taking board seats and proactively leveraging extensive corporate resources to create value for biotech startups and the independent VCs. For example, SR One, based in Conshocken, Pennsylvania, publicly states that they align with other investors and do not require specific product rights or options in their investments.

Create value-based incentives. A fifth principle that emerged from our survey is the move to provide greater incentives to the managers of the fund. Traditionally, professionals in corporate venture units were rewarded with flatrate salaries, like most corporate management. Despite evidence pointing to the positive effect of performance-related compensation schemes on venturing activities ${ }^{12}$, pharmaceutical firms were particularly hesitant to adopt such measures due to cultural and structural barriers. In our study, however, we found value-based incentives to be a component of the overall compensation package in corporate VC units. Although a flat-rate corporate salary is largely adopted (62\%), the use of value-based incentives, especially for senior professionals, applies to $38 \%$ of the sample (notably, $32 \%$ adopted bonuses based on financial and strategic performance). The increased use of performance-related incentives may have a positive effect on interest alignment, external recruitment and talent retention. More importantly, the new incentive schemes should enable better alignment with interests held more widely by investors in the $\mathrm{VC}$ community.

Install performance metrics. Our survey also revealed that performance metrics are now an integral part of how funds are managed. We uncovered a systematic use of multiple performance metrics. Most firms (90\%) not only have a broad range of key performance indicators (KPIs), including metrics for financial and strategic returns (Fig. 4), but also define performance and management-related target values (70\%).

The KPIs are particularly important to improve clarity on goals and alignment with the strategic objective of the venturing initiative. For example, the Novo Nordisk Biotech Fund, based in Copenhagen, uses a broad set of criteria to evaluate their investments, including the strength of the venture's management team, the intellectual property (IP) positions, the quality of the science and technology, and the financial positions. The overall venture unit performance is additionally evaluated on a $2 \times 2$ matrix that plots the financial value (for example, initial corporate investment versus fair market value $=$ yield $)$ against strategic value (for example, number of collaborations or impact on corporate business). The use of KPIs serves as an important feedback mechanism to capture (and demonstrate) the value created by the venturing activities, moving beyond the assessment of performance on the basis of traditional measures, such as the number of deals screened or made. With a coherent range of effective KPIs in place, today's corporate venture units are better positioned to balance their financial orientation on the internal rate of return and financial gain of portfolio startups with the innovation and growth targets of the parent firm. 
To summarize, our study reveals that the corporate venturing practice of pharmaceutical firms toward biotech ventures has substantially evolved during recent years. The pharmaceutical firms are increasingly implementing the six principles that allow them to overcome the limitations of the past. In the process, these firms able to partner more equitably with external VCs and biotech ventures. Accordingly, pharmaceutical firms have moved beyond the decision of whether or not to engage in venturing to shape the best governance, models and practices. The changing face of corporate venturing involves a shift from 'if' to 'how'.

\section{Take-home messages for entrepreneurs}

From the point of view of a biotech entrepreneur, what do the data from our survey tell us about corporate venturing? At a time in which the market for traditional venture financing is dwindling, with traditional VC funds refocusing their investments away from early stage biotech startups, corporate investors represent an alternative route to financing. At present, however, corporate venturing is the least understood (and appreciated) form of VC. Although some entrepreneurs appear to be overwhelmingly concerned about potential conflict of interests or IP protection, our study finds that many of the traditional worries are often misplaced. Indeed, four aspects of corporate venturing are particularly important when considering how to finance a startup.

First, corporate venture funds may provide biotech startups with strategic benefits beyond investment capital. These include the opportunity to access technology, research are becoming reliable and professional investors,

knowledge and capacity, drug development expertise, marketing competence and (often) a global presence. Pharmaceutical firms often help facilitate the identification of valuable commercial applications. In essence, biotech entrepreneurs should look for a strategic fit between their technology and research capabilities and the therapeutic and/or technological areas of the pharmaceutical firm with which they would like to work. For example, although some funds only invest in science-based ventures, other funds such as Lilly Ventures invest in healthcare-enabling technologies and business models such as the innovation consultancy Innocentive. Another advantage is brand recognition of the large firm. The venture's association with a strong brand is likely to signal quality and increase its visibility, channeling the attention of top-tier investors for subsequent rounds of financing.

Second, corporate venture units are most often part of large established organizations that perhaps are slow and bureaucratic but are also resilient. During the past economic downturn, although the market for traditional VC funding was curtailed, existing corporate venture funds kept their size with several new initiatives being added, highlighting a change in the strategy of pharmaceutical firms from previous VC cycles. The evidence on the longevity of the corporate venture programs suggests that, contrary to common perceptions, the reliability and level of engagement of the pharmaceutical firms is, at least, comparable with that of traditional VC funds.

Third, corporate venturing should not be considered on the basis of the expectation of receiving a valuation significantly higher than

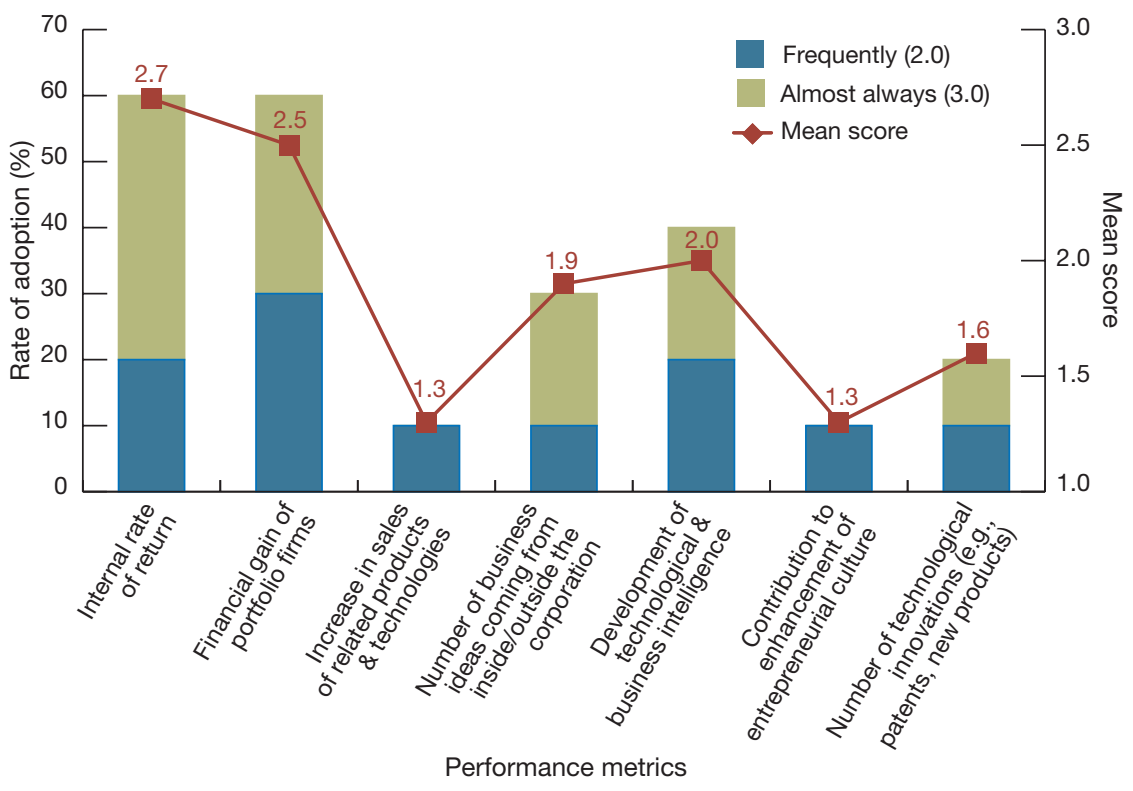

Figure 4 Rate of adoption (\%) of performance metrics by corporate venture capital funds (by type). the average valuation of independent VCs. This is nothing but a misconception. Rather, biotech entrepreneurs should consider that the backing of a corporate venture unit is more likely to lead to successful exits (M\&As and IPOs), higher post-money valuation and longer-term valuation measures ${ }^{13}$.

Fourth, biotech entrepreneurs should ask for appropriate firewalls between the evaluation team of the corporate venture unit and the parent company to prevent the unsolicited spillover of sensitive information about strategy or technology to the parent firm. Compliance with such practice is also in the interest of venture units. SR One and Takeda Ventures, for example, maintain a tight firewall policy on confidential items received from portfolio companies or an investment opportunity under review.

\section{Conclusions}

Corporate venturing by multinational pharmaceutical and large biotech companies is playing an increasingly important role in financing the development of early stage innovation. Today's corporate venturing has a new face-and it is more attractive for biotech ventures and the VC community. Companies with VC funds have learned from past mistakes and today play an essential role in the sustainability of the biotech ecosystem, advancing the future of pharmaceutical innovation and biotech entrepreneurship.

\section{COMPETING FINANCIAL INTERESTS}

The authors declare no competing financial interests.

\section{ACKNOWLEDGMENTS}

We are grateful to Alexander Pertot, Thomas Lustgarten and Norbert Hültenschmidt from Bain \& Company, and Fredrik Hacklin from ETH Zurich for their support and participation in the Corporate Venturing Research Initiative. We would also like to thank Ulrich Geilinger, Jascha Forster and Chandra Leo from HBM Partners for their research assistance and contribution.

1. PricewaterhouseCoopers \& National Venture Capita Association. MoneyTree Report Q2 2012.<http://www. nvca.org/index.php?option=com_docman\&task=cat_ view\&gid $=99 \& \mid$ temid $=317>(2012)$.

2. Huggett, B. Nat. Biotechnol. 30, 395-400 (2012).

3. Kneller, R. Nat. Rev. Drug Discov. 9, 867-882 (2010)

4. Ernst \& Young. Beyond borders: global report 2011 $<$ http://www.ey.com/Publication/vwLUAssets/Beyond_borders_global_biotechnology_report_2011/\$FILE/Beyond borders global biotechnology report 2011.pdf> (2011).

5. Booth, B.L. \& Salehizadeh, B. Nat. Biotechnol. 29 579-583 (2011).

6. Gompers, P.A. Economic Rev. 1-17 (2002)

7. Singh, V. The Burrill Report 2(6), 10 (2012).

8. Booth, B.L. Nat. Biotechnol. 27, 705-709 (2009).

9. Kessel, M. Nat. Biotechnol. 29, 27-33 (2011).

10. Dushnitsky, G. Business Strategy Review 22(3), 44-49 (2011).

11. Basu, S., Phelps, C.C. \& Kotha, S. Journal of Business Venturing 26, 153-171 (2011).

12. Dushnitsky, G. \& Shapira, Z. Strategic Management Journal 31, 990-1017 (2010).

13. Henderson, J. International Journal of Technoentrepreneurship 2, 29-44 (2009). 